\title{
STUDI TENTANG KEMAMPUAN SPASIAL SISWA SEKOLAH MENENGAH PERTAMA (SMP) DI MOJOKERTO
}

\author{
Rizky Oktaviana Eko Putri ${ }^{1}$, Ulil Nurul Imanah ${ }^{2}$ \\ Universitas Islam Majapahit, Jalan Raya Jabon KM 7, Mojokerto \\ 1rizky_putri@unim.ac.id
}

\begin{abstract}
Abstrak
Kemampuan spasial adalah aktivitas kognitif untuk menvisualisasikan objek dalam pikiran termasuk kemampuan untuk mengubah sudut pandang ketika melihat sebuah objek. Kemampuan spasial sangat penting dalam pembelajaran Geometri. Namun, ada kecenderungan dalam pembelajaran tidak memperhatikan aspek ini. Hal ini dapat dilihat dari guru yang hanya focus pada kemampuan siswa dalam penyelesaian masalah. Penelitian ini dilakukan untuk menginvestigasi kemampuan spasial dari siswa SMP. Subjek dalam penelitian adalah siswa kelas VIII SMP di kota Mojokerto. Penelitian ini adalah penelitian deskriptif dengan pendekatan kuantitatif. The Purdue Spatial Visualization Test (PSVT) digunakan untuk mengumpulkan data kemampuan spasial siswa. Subjek penelitian dikelompokkan ke dalam tiga kategori kemampuan spasial, yaitu kemampuan spasial tinggi, sedang dan rendah. Dari analisis statistik diperoleh data bahwa mayoritas siswa berada pada tingkat kemampuan spasial sedang, dengan presentase sebesar $69 \%$. Sedangkan sisanya berada pada tingkat kemampuan spasial tinggi, yaitu $16 \%$, dan kemampuan spasial rendah, yaitu sebesar $15 \%$. Selanjutnya, berdasarkan analisis data disarankan pada guru untuk menciptakan pembelajaran yang dapat meningkatkan kemampuan spasial siswa.
\end{abstract}

Kata Kunci: Kemampuan Spasial, The Purdue Spatial Visualization Test (PSVT)

\begin{abstract}
Spatial ability is a cognitive activity to visualize objects into mind involving the ability to move things mentally and change the point of view when looking at an object. Spatial ability is essential for learning geometry as one of the mandatory subject in mathematics education. Unfortunately, there is a tendency that teaching activities ignore this aspect. This can be seen as teachers only focused on students' solving problems ability. This study was conducted to investigate the spatial ability of junior high school students. This study was using spatial skills element. The data were collected from seventh grade students in junior high schools in Mojokerto. This is a descriptive study that using the quantitative approach. The Purdue Spatial Visualization Test (PSVT) was used to identify the students' spatial skill. The PSVT consists of 30 problems that can measure all the three students' spatial skill elements. Participants were categorized into three spatial skill levels based on PSVT result; high, intermediate, and low level spatial skill. Statistical analysis indicated the majority of the participants, as 69 percents, possessed spatial skill in intermediate level, whereas the other was in high level, as 16 percents, and low level of spatial skill. Furthermore, qualitative analysis reveals that most students have difficulty in solving problem for spatial rotation elements. This problem mostly appeared in intermediate and low level spatial skill students. Finally, the data analysis recommends teachers provide activities to improve students' spatial skills.
\end{abstract}

Keywords: spatial ability, The Purdue Spatial Visualization Test (PSVT) 


\section{Pendahuluan}

Geometri merupakan salah satu mata cabang ilmu dalam matematika yang wajib dipelajari siswa mulai dari Sekolah Dasar (SD) hingga Sekolah Menengah Atas (SMA). Hal ini dapat terlihat dalam kurikulum yang digunakan selalu melibatkan geometri sebagai salah satu materi yang wajib dikuasai. Berdasarkan hasil observasi awal dan wawancara dengan beberapa guru matematika di SMP, siswa banyak mengalami kesulitan dalam menyelesaikan permasalahan matematika yang berkaitan dengan geometri. Hal tersebut disebabkan karena siswa kesulitan untuk membayangkan suatu benda dalam benak mereka. Kemampuan dalam menvisualisasikan benda ke dalam pikiran tersebut sering disebut sebagai kemampuan spasial.

Sorby (2009) dan Tartre (1990) menyatakan bahwa kemampuan spasial adalah suatu proses mental yang melibatkan kemampuan untuk menggerakkan benda secara mental dan merubah sudut pandang saat melihat suatu benda. Piaget \& Inhelder (dalam Tambunan, 2006) menyatakan bahwa kemampuan spasial sebagai konsep abstrak yang di dalamnya meliputi hubungan spasial (kemampuan untuk mengamati hubungan posisi objek dalam ruang), kerangka acuan (tanda yang dipakai sebagai patokan untuk menentukan posisi objek dalam ruang), hubungan proyektif (kemampuan untuk melihat objek dari berbagai sudut pandang), konservasi jarak (kemampuan untuk memperkirakan jarak antara dua titik), representasi spasial (kemampuan untuk merepresentasikan hubungan spasial dengan memanipulasi secara kognitif), rotasi mental (membayangkan perputaran objek dalam ruang). Sedangkan Clements (1998) mendefinisikan kemampuan spasial sebagai operasi mental dalam membangun sebuah organisasi atau membentuk sebuah objek atau kumpulan objek. Penataan spasial dari sebuah benda dalam menentukan sifatnya atau bentuknya dilakukan dengan mengidentifikasi bagianbagian spasial dari benda tersebut, menggabungkan bagian-bagian benda ke dalam komposit spasial dan membangun hubungan di antara setiap bagian dan setiap komposit dari benda tersebut. William, et al. (2010) memandang kemampuan spasial sebagai penalaran spasial yaitu kemampuan yang melibatkan representasi dan penggunaan objek-objek dan hubungan antar objek dalam kehidupan nyata. Sedangkan Kayhan (2005) mendefinisikan kemampuan spasial sebagai kemampuan untuk memanipulasi, mengorganisasikan atau mengintrepretasikan hubungan secara visual.

Banyaknya definisi tentang kemampuan spasial menimbulkan banyak pula munculnya definisi tentang komponen dalam kemampuan spasial (Yilmaz, 2009; Kayhan, 2005). Namun secara garis besar terdapat tiga komponen utama dalam kemampuan spasial (Turğut \& Yilmaz, 2012) yaitu Rotasi Spasial (Spatial Rotation), Visualisasi Spasial (Spatial Visualization), dan Persepsi Spasial (Spatial Perception). Persepsi Spasial adalah jenis kemampuan spasial yang menuntut subjek untuk menentukan hubungan spasial sehubungan dengan informasi yang telah diketahui, Rotasi Spasial adalah kemampuan untuk yang menuntut subjek untuk memutar gambar dua dimensi atau tiga dimensi secara berulang dan akurat, dan Visualisasi Spasial adalah kemampuan yang menuntut subjek untuk melakukan manipulasi informasi secara spasial. Untuk mengukur kemampuan spasial dapat dilakukan dengan menggunakan The Purdue Spatial Visualization Test-Visualization of Rotations (PSVT), dimana dalam tes tersebut subjek diberi soal yang berupa gambar dua dimensi dan subjek dituntut untuk memilih gambar yang paling sesuai setelah dilakukan rotasi dalam berbagai arah dan posisi. Kemampuan spasial diperoleh anak secara bertahap, dimulai dari pengenalan objek melalui persepsi dan aktivitas anak di lingkungannya. Mulai dari orientasi yang sifatnya egosentris yaitu menekankan pada dirinya sebagai patokan dalam melihat hubungan spasial, semakin bertambahnya usia patokan tersebut berkembang menjadi patokan 
orang dan patokan objek. Menurut Piaget (2000) kemampuan spasial yang merupakan aspek dari kognisi berkembang sejalan dengan perkembangan kognitif yaitu konsep spasial pada tahapan sensori-motor, konsep spasial pada tahapan pra-operasional, konsep spasial pada tahapan konkret-operasional dan konsep spasial pada tahapan formal-operasional.

Kemampuan spasial seseorang dapat mempengaruhi kemampuan matematika, hal ini ditunjang dengan hasil penelitian yang menunjukkan bahwa kemampuan spasial memiliki hubungan yang positif dengan kemampuan siswa dalam menyelesaikan masalah (Gardner, 2011 ; Turğut and Yilmaz, 2012 ; Rabab'h and Arsaythamby, 2015 ; Verdine, et. al, 2013 ; Hannafin et al., 2010 ; Hanifah, et al, 2018). Siswa dengan kemampuan spasial yang baik dan tertarik dengan geometri cenderung memiliki kemampuan matematika tinggi (Yenilmez, K. and Kakmaci, O., 2015). Untuk mengatasi permasalahan yang tersebut, guru telah melakukan berbagai cara saat pembelajaran. Akan tetapi scaffolding yang diberikan oleh guru terkadang kurang memperhatikan aspek spasial, sehingga siswa yang memiliki kemampuan spasial rendah akan cenderung tetap mengalami kesulitan dalam memahami materi yang diberikan. Untuk melatih dan meningkatkan kemampuan spasial siswa, guru harus dapat menjembatani dunia nyata dengan pikiran atau imajinasi siswa (Sorby, 2009).

Dengan fakta yang telah diuraikan tersebut, peneliti tertarik untuk melihat kemampuan spasial siswa SMP. Alasan utama mengadakan penelitian ini kepada siswa SMP karena siswa berada di tahap awal operasi formal, artinya siswa sudah mulai berpikir secara abstrak (Piaget, 2000). Mempertimbangkan hal tersebut perlu adanya pembelajaran yang memperhatikan setiap aspek kemampuan siswa, dalam hal ini adalah kemampuan spasial.

\section{Metode Penelitian}

Penelitian ini merupakan salah satu jenis penelitian deskriptif dengan pendekatan kuantitatif. Tujuan dari penelitian ini adalah mendeskripsikan kemampuan spasial siswa Sekolah Menengah Pertama (SMP). Subjek dalam penelitian ini adalah 225 orang siswa dari delapan sekolah SMP Negeri yang berada di kota Mojokerto. Siswa yang menjadi subjek penelitian adalah siswa kelas VIII pada semester genap tahun ajaran 2017/2018 di masingmasing sekolah. Alasan pemilihan subjek ini karena siswa sudah berada di tahap awal operasi formal, artinya siswa sudah mulai berpikir secara abstrak (Piaget, 2000). Selain itu siswa pada kelas VIII telah mempelajari materi geometri, terutama bangun datar dan bangun ruang. Mempertimbangkan hal tersebut perlu adanya pembelajaran yang memperhatikan setiap aspek kemampuan siswa, dalam hal ini adalah kemampuan spasial. Langkah pertama dalam pemilihan subjek adalah penentuan kelas yang akan dipakai untuk penelitian. Kriteria utama pemilihan kelas yaitu siswa dalam kelas tersebut harus memiliki kemampuan matematika yang heterogen. Informasi tentang kemampua siswa diperoleh dari wawancara dengan guru pengampu mata pelajaran Matematika di sekolah yang dituju.

Teknik pengumpulan data pada penelitian ini menggunakan metode tes. Data yang dimaksud adalah hasil tes kemampuan spasial mahasiswa yang menggunakan Purdue Spatial Visualization Tests (PSVT). Tes ini terdiri dari 30 soal pilihan ganda dimana siswa diberi soal yang berupa gambar dua dimensi dan siswa dituntut untuk memilih gambar yang paling sesuai setelah dilakukan rotasi dalam berbagai arah dan posisi. Berikut salah satu contoh soal dalam PSVT 


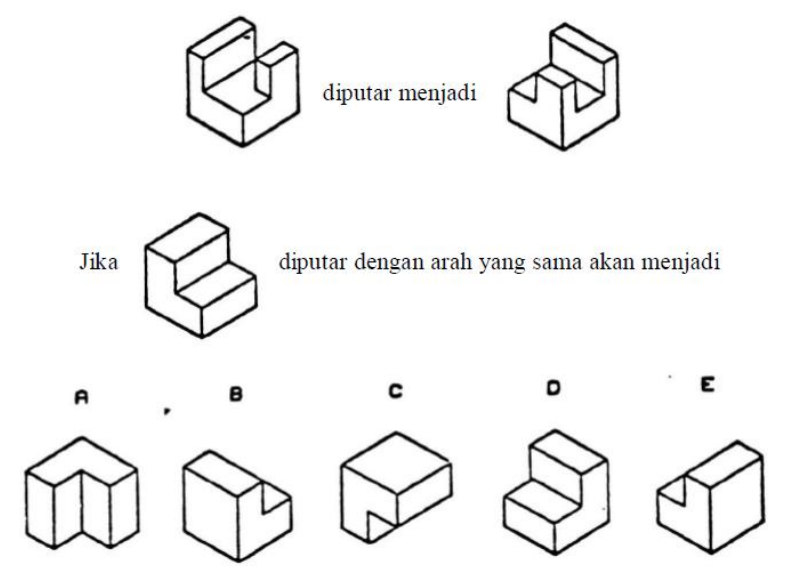

Gambar 1. Salah satu soal PSVT

Penelitian ini menggunakan pengkategorian kemampuan spasial siswa dengan menggunakan skor skala, yaitu pengkategorian variabel menjadi tiga golongan (tinggi, sedang, dan rendah) berdasarkan nilai rata-rata $(\mu)$ dan standar deviasi $(\sigma)$. Kategori tersebut disajikan dalam tabel berikut (Azwar, 2010):

Tabel 1. Kategori Kemampuan Spasial Siswa

\begin{tabular}{|l|c|l|}
\hline No. & Interval & Kategori \\
\hline 1. & $\mu+1,0 \sigma \leq X$ & Tinggi \\
\hline 2. & $\mu-1,0 \sigma \leq X<\mu+1,0 \sigma$ & Sedang \\
\hline 3. & $X<\mu-1,0 \sigma$ & Rendah \\
\hline
\end{tabular}

\section{Hasil dan Pembahasan}

Pengambilan data untuk kemampuan spasial dilakukan pada semester genap tahun ajaran 2017/2018. Siswa yang menjadi subjek penelitian diharuskan mengerjakan soal Purdue Spatial Visualization Tests (PSVT) yang berupa pilihan ganda dalam waktu 30 menit. Berdasarkan analisis data Purdue Spatial Visualization Tests (PSVT) secara statistik diperoleh hasil sebagai berikut:

Tabel 2. Hasil analisis PSVT

\begin{tabular}{|c|c|c|c|c|c|}
\hline & $\mathrm{N}$ & $\begin{array}{c}\text { Mini- } \\
\text { mum }\end{array}$ & $\begin{array}{c}\text { Max- } \\
\text { imum }\end{array}$ & Mean & Std. Deviation \\
\hline NILAI & 225 & 7.00 & 97.00 & 44.4489 & 18.65711 \\
\hline $\begin{array}{c}\text { Valid N } \\
\text { (listwise) }\end{array}$ & 225 & & & & \\
\hline
\end{tabular}

Subjek dalam penelitian adalah 225 orang siswa kelas VIII dari delapan SMP yang berada di kota mojokerto. Nilai tertinggi yang diperoleh dari hasil tes adalah 97 dan terendah adalah 7 dengan rata-rata nilai secara keseluruhan adalah 44 dan standar deviasi sebesar 19 . Selanjutnya dilakukan pengelompokan subjek berdasarkan hasil tes PSVT ke dalam tiga kategori tingkat kemampuan spasial, dengan hasil sebagai berikut: 


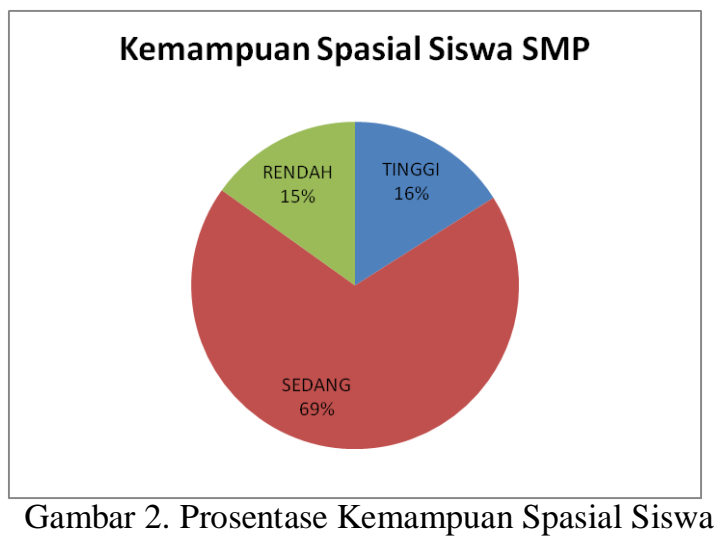

Berdasarkan diagram di atas terlihat bahwa mayoritas siswa, sebanyak 155 orang, memiliki kemampuan spasial pada tingkat sedang yaitu sebesar $69 \%$. Sedangkan siswa dengan tingkat kemampuan tinggi dan rendah memiliki prosentase yang hampir sama, hanya selisih 1 persen, yaitu 36 orang atau sebesar 16\% untuk siswa dengan kemampuan tinggi dan $15 \%$ atau setara dengan 34 orang untuk siswa dengan kemampuan rendah.

Sebagian besar siswa melakukan kesalahan untuk kriteria soal yang sama, yaitu soal yang menggambarkan benda yang dirotasikan lebih dari satu kali. Hal ini sesuai dengan hasil dari Putri (2018); Bodner \&Guay (1997) dan Caissie, Vigneau, \& Bors (2009) yang menyatakan bahwa hanya siswa dengan kemampuan spasial tinggi yang mampu menjawab soal dengan rotasi ganda dengan benar. Berikut ini adalah contoh soal dengan arah rotasi lebih dari satu kali.

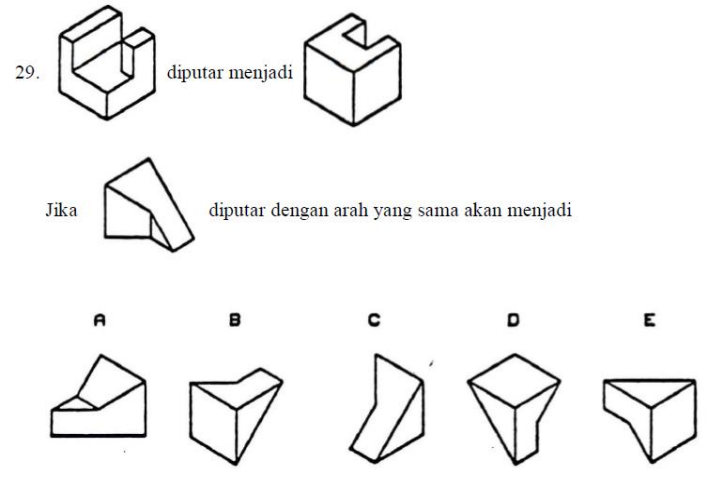

Gambar 3. Soal PSVT dengan dua kali rotasi

Hasil kemampuan spasial yang diperoleh dalam penelitian ini menunjukkan bahwa kemampuan spasial siswa cenderung masih rendah. Hal ini dapat berpengaruh dalam kemampuan siswa dalam matematika. Beberapa penelitian menunjukkan bahwa ada hubungan positif antara kemampuan spasial dengan prestasi siswa dalam matematika, khususnya kemampuan siswa dalam menyelesaikan masalah yang berkaitan dengan soal matematika (Gardner, 2011 ; Turğut and Yilmaz, 2012 ; Rabab'h and Arsaythamby, 2015 ; Verdine, et. al, 2013 ; Hannafin et al., 2010 ; Hanifah, et al, 2018). 
Berkaitan dengan hasil penelitian tersebut maka perlu adanya pebelajaran yang melibatkan aspek spasial sehingga siswa dapat meningkatkan kemampuan spasial mereka (Newcombe, 2013). Beberapa cara yang dapat dilakukan untuk meningkatkan kemampuan spasial siswa dalam kegiatan pembelajaran khususnya pembelajaran matematika adalah dengan penggunaan media pembelajaran. Media pembelajaran ini dapat berupa media manual (solid modeling) atau dengan bantuan software (Koch, 2006; Maier, 1996).

\section{Simpulan dan Saran}

Berdasarkan hasil analisis data didapatkan kesimpulan bahwa mayoritas siswa yang menjadi subjek penelitian mempunyai kemampuan spasial sedang yaitu sebesar $69 \%$ dari 225 siswa SMP. Kemampuan spasial merupakan salah satu aspek yang mempengaruhi kemampuan siswa dalam matematika, khususnya dalam bidang geometri. Hasil dari beberapa penelitian menunjukkan bahwa kemampuan spasial memiliki pengaruh positif dengan kemampuan pemecahan masalah geometri siswa. Oleh karena itu guru perlu memperhatikan aspek ini dalam kegiatan pembelajaran. Penelitian ini merupakan penelitian awal (preliminary study) yang selanjutnya akan dilanjutkan dengan melihat seberapa besar pengaruh kemampuan spasial siswa SMP dalam penyelesaian masalah geometri. Penelitian ini didanai oleh Kemenristek DIKTI sebagai bagian dari Penelitian Dosen Pemula (PDP)

\section{Referensi}

Azwar, Saifuddin. (2010). Metode Penelitian. Yogyakarta: Pustaka Pelajar

Bakker, A., Smit, J. and Wegerif, R., (2015). Scaffolding and dialogic teaching in mathematics education: Introduction and review. ZDM Mathematics Education, 47:1047.

Battista, M.T. (1990). Spatial Visualization and Gender Differences in High School Geometry. Journal for Research in Mathematics Education, 21 (3), 47-60.

Bodner, G. M., \&Guay, R. B. (1997). The Purdue visualization of rotations test. The Chemical Educator, 2(4), 1-17.

Caissie, A. F., Vigneau, F., \& Bors, D. A. (2009). What does the Mental Rotation Test measure? An analysis of item difficulty and item characteristics. Open Psychology Journal, 2(1), 94-102.

Clements, Douglas H. (1998). Geometric and Spatial Thinking in Young Children. Opinion paper National Science Foundation.

Hanifah, U., Juniati, D., \& Siswono, T. Y. E. (2018, January). Students' Spatial Performance: Cognitive Style and Sex Differences. In Journal of Physics: Conference Series (Vol. 947, No. 1, p. 012014). IOP Publishing.

Kayhan, E.B. (2005). Investigation of High School Students' Spatial Ability. Dissertation, Ankara: Middle East Technical University.

Koch, D. S. (2006). The effects of solid modeling and visualization on technical problem solving (Doctoral dissertation, Virginia Tech).

Maier, P. H. (1996, March). Spatial geometry and spatial ability-How to make solid geometry solid. In Selected papers from the Annual Conference of Didactics of Mathematics (pp. 63-75).

Newcombe, N. S. (2013). Seeing Relationships: Using Spatial Thinking to Teach Science, Mathematics, and Social Studies. American Educator, 37(1), 26. 
Putri, R. O. E. (2018, January). Spatial Skill Profile of Mathematics Pre-Service Teachers. In Journal of Physics: Conference Series (Vol. 947, No. 1, p. 012065). IOP Publishing.

Sorby, S. A. (2009). Developing 3-D spatial visualization skills. Engineering Design Graphics Journal, 63(2).

Tambunan, Siti Marliah. (2006). Hubungan antara Kemampuan Spasial dengan Prestasi Belajar Matematika. Makara, sosial humaniora, vol. 10, no. 1, pp. 27-32

Tartre, L. A. (1990). Spatial orientation skill and mathematical problem solving. Journal for Research in Mathematics Education, 216-229.

Turğut, Melih \& Süha Y1lmaz. (2012). Relationships Among Preservice Primary

Mathematics Teachers' Gender, Academic Success and Spatial Ability. International Journal of Instruction. Vol.5, No.2 e-ISSN: 1308-1470 . www.e-iji.net

Verdine, Brian N., dkk. (2013). Deconstructing Building Blocks: Preschoolers' Spatial Assembly Performance 1 Relates to Early Mathematical Skills. CDEV journal. Child Development, pp 1-14. DOI: 10.1111/cdev.12165

Williams, C.B. et al. (2010). Exploring Spatial Reasoning Ability and Design Cognition in Undergraduate Engineering Students, Proceedings of the ASME 2010 International Design Engineering Technical Conference \& Computers and Information in Engineering Conference, 1-8.

Yenilmez, Kursat \& Ozlem Kakmaci. (2015). Investigation of the Relationship between the Spatial Visualization Success and Visual/Spatial Intelligence Capabilities of Sixth Grade Students. International Journal of Instruction. Vol. 8 no. 1. Pp 189-204

Y1lmaz, H.B. (2009). On the Development and Measurement of Spatial Ability. International Electronic Journal of Elementary Education, 1 (2), 83-96. 